\title{
THE INFLUENCE OF TRAINING METHOD AND MUSCLE CONSTRUCTION TOWARDS TAEKWONDO KICK CAPABILITY
}

\author{
Jonas Solissa \\ Penjaskesrek Study Program \\ Faculty of Teacher Training and Educational Sciences \\ Pattimura University, Maluku \\ email : jonassolissa@gmail.coom
}

\begin{abstract}
This study aims to determine the effect of circuit training methods and interval training methods on the ability of the Taekwondo Round-House kick. The study was carried out at Unpatti Taekwondo athletes in Ambon 2019, using an experimental method with 2 × 2 factorial design. Data were analyzed using Variant Analysis (ANOVA).The results showed, that: (1) Overall there was a difference in the ability of Taekwondo Round-House kick between the circuit training method and the interval training method, (2) For taekwondoin who had high muscle flexibility, the interval training method was better than the circuit training method for Taekwondo RoundHouse Kick ability, (3) For taekwondoin which has low muscle flexibility, there is no significant difference between the circuit training method and the interval training method for Taekwondo Round-House kick capability. (4) There is an interaction between the training methods with the flexibility of the Taekwondo dolyo kick ability.
\end{abstract}

Keywords: Training methods, flexibility, kicking ability, taekwondo.

\section{Introduction}

Coaching and development in a sport is part of an effort to improve sports performance, but to achieve this it needs a careful planning through an integrated, systematic and continuous coaching system.

Focusing on the region of Maluku, the quality of Taekwondo sporting achievement is still lacking compared to other regions. This can be seen from the five-fold improvement in PON activity which has been very drastic. In PON XV Taekwondo got 1 gold, 2 silver 2 bronze, PON XVI Taekwondo got 5 bronze, PON XVII Taekwondo got 1 bronze, PON XVIII Taekwondo got 1 bronze, and PON XIX Taekwondo did not receive any medal.

This decline in achievement when examined from a technical perspective has weaknesses in the coaching process. The intended weakness is related to the process of fostering physical conditions carried out by trainers in an unsystematic manner. This can be seen when participating in matches, taekwondo in (taekwondo athletes) cannot last until the final round. Taekwondo in conditions like this occur when the competition is held both at the regional level and at the national level.

Factors causing the physical condition of taekwondo in as above are due to the physical condition training process which is only directed at the reaction speed training during the training season. In the preparation period, the trainer does not lay / establish general physical conditions followed by specific physical improvements to obtain and realize all the requirements needed for achievement.

To optimize the physical condition of taekwondo in based on the description above, scientific solutions are needed in finding the right training methods to solve these problems. Development of physical conditions in order to improve the ability of Taekwondo kicks can be done using the circuit training method and the interval training method. According to Rothing and Grossing (1985: 42) the circuit training method is an exercise performed in 
a circuit consisting of several stations to improve physical abilities. According to Harsono (1988: 226) circuit training is a training system that in addition to producing positive changes in motor ability, which simultaneously improves physical fitness from the body, muscle strength, endurance, speed and flexibility. Furthermore according to Tangkudung (2006: 68) circuit training is one way to simultaneously improve the overall fitness level of our body including basic bio-motor components.

While the Interval training method is a form of repetitive training where the training load, training intensity and rest time have been previously designed by the trainer for a goal to be achieved (Solissa, 2016: 72). According to Rainer Martens (2004: 313) interval training is a form of exercise that is interspersed with periods of rest or release. Furthermore according to Russhal (1990: 124) Interval training is a form of training that was born from a mythology from Sisyphus, which is referred to as the god of death. Now increasingly popular and used as one part of training programs that are very important in the modern training schedule.

The training to improve the ability of Taekwondo kicks through the second approach of the exercise method above must be supported by high muscle flexibility. According to Wilmore and Costil (1994) flexibility is the ability of the body or limbs to make the broadest possible movement. According to Kent (1994) flexibility is a measure of how far a person can move the limbs, arms, and body in their own joints. Baechle and Groves (1997) state that flexibility is a movement that moves the muscles of the joint. According to Bompa (2009) flexibility is a prerequisite needed to display a skill that requires extensive joint gauze and makes it easy to do fast and agile movements. To achieve optimal performance, muscle elasticity must be improved as an underlying foundation in improving technical skills in sports.

Referring to the description above, the study related to the development of physical conditions in Taekwondo deserves to be examined. Therefore, it is deemed necessary to have an appropriate training method in improving kicking ability in order to develop Taekwondo achievements in general and specifically in Maluku.

The problems of this study are: 1 ). Is there an overall difference between the circuit training method and the interval training method for the Taekwondo Round-House kick ability? 2). Is there a difference in the ability of Taekwondo Round-House kick between taekwondo in trained with the circuit training method and the interval training method in the high muscle group? 3). Is there a difference in the ability of Taekwondo Round-House kick between taekwondo in trained by the circuit training method and the interval training method in the low muscle group? 4). Does the interaction between the training method and muscle flexibility affect the ability of the Taekwondo Round-House kick?

The hypotheses in this study included: first, Overall the circuit training method is superior to the interval training method of the Taekwondo Round-House kick ability, second one, the circuit training method is superior to the interval training method for the ability of the Taekwondo Round-House kick in the high muscle group, third, the interval training method is superior to the circuit training method for Round-House kicking ability in the low muscle flexibility group and the last there is an interaction effect between the training method and muscle flexibility on the ability of the Taekwondo Round-House kick.

\section{Research Methodology}

The method used in this study is an experimental method with the design of Treatmen by Level $2 \times 2$. The population is 80 people, taken with certain considerations (purposive sampling). Determination of the sample using the technique percentage of $27 \%$ for the upper limit representing the high muscle strength group and $27 \%$ the lower limit 
representing the low muscle strength group and the division of cell groups by drawing. The number of samples in this study were 40 people, divided into 4 cells, each cell 10 people.

The research instruments used for data collection, namely: (1) endurance instruments, were developed to measure the ability of Round-House kicks, and (2) instruments of muscle flexibility were measured using a Leg Dynamometer. Side and rice.

The data obtained in this study were processed and analyzed using a two-way variance analysis (ANOVA) technique with a significant level of $\alpha 0.05$ and followed by a tuckey test. To test the normality of the data used Liliefors test and to test the homogeneity of the data used the Barlet test.

\section{Result and Discussion}

The process of discussing the results of research in detail from each variable based on research findings and based on hypothesis testing, is as follows:

a. There is a Difference in the Ability of the Round-House Kick between the Circuit Training Method and the Interval Training Method. Based on the analysis of variance (ANOVA) at a significant level $\alpha=0.05$, it can be Fcount $=6.262986$ and Ftable $=2.09$ or Fcount> Ftable with a significance of 0.002 . It can be concluded that overall, there is a significant difference between the circuit training method and the interval training method on the Taekwondo Round-House kicking ability. In other words, the ability to kick using the circuit training method $=122,786$ is greater than the interval training method $=105,851$. This means, that the research hypothesis which states that overall there is a difference in the ability to kick between the circuit training method with the interval training method is proven. From the ANOVA test results, it was found that there were significant differences between the circuit training method and the interval training method on the Round-House Taekwondo kick capability.

b. There is a Difference between the Effect of Circuit Training Method and Interval Training Method on Round-House Kick Ability for High Muscle Specificity Groups. The circuit training method has an effect on the ability to Round-House Kick in groups that have high muscle flexibility. This was proven based on the results of further tests in the analysis of variance (ANOVA) using the Tuckey test, the high muscle flexibility treatment group using the circuit training method (A1B1) compared to the high muscle flexibility treatment group with the interval training method (A2B1), obtained Q count $=4,977762$ and Qtable $=2.26$. Thus Qcount is greater than Qtable, so Ho is rejected. It can be interpreted that there is a significant difference in the increase in Round-House kick capability between the circuit training method and the interval training method on high muscle flexibility. In other words, that taekwondo in which has high muscle flexibility using the circuit training method $=62,579$ is greater than the interval training method $=$ 43,544 in the Taekwondo Round-House kick capability. Thus, the research hypothesis is proven to prove that high muscle flexibility with the circuit training method is better than the interval training method in increasing the ability of the Taekwondo Round-House kick. c. There is a Difference between the Effects of the Circuit Training Method and the Interval Training Method on Increasing the Ability of the Round-House Kick for the Low Muscle Flexibility Group

The circuit training method has no effect on increasing kicking ability in groups that have low muscle flexibility. This was not proven based on the results of further tests in the analysis of variance (ANOVA) using the Tuckey test, the low muscle flexibility treatment group with the circuit training method (A1B1) compared to the low muscle flexibility treatment group with the interval training method (A2B1), obtained Q count = 0.549162 and Qtable $=2.26$. Thus Qcount is smaller than Qtable, so Ho is accepted. It can be interpreted that there is no significant difference in the ability to Round-House kick 
between the circuit training method and the interval training method on low muscle flexibility.

In other words, that taekwondo in which has low muscle flexibility using the circuit training method $=0.549162$ is smaller than the interval training method $=2.26$ in the Taekwondo Round-House kick capability. Thus, the research hypothesis is proven to prove that low muscle flexibility with the interval training method is better than the circuit training method in increasing the ability of the Taekwondo Round-House kick.

d. There is an Interaction between the Training Method and the Flexibility in Improving Taekwondo Round-House Kicking Ability. The results of the analysis of variance about the interaction between the training method and muscle flexibility on kicking ability, that the price of interaction Fo $(\mathrm{FAB})=\mathrm{F}$-count $=16.823>$ Ftable $=4.00$ at $\alpha=0.05$ (significance of 0.000) It appears that Fcount> Ftable, so Ho was refused. The conclusion is that there is an interaction between the training method and the muscle flexibility of the Taekwondo Round-House kick ability.

With the testing of these interactions, then further tests need to be done. Further tests are intended to find out about: a) The difference between the effect of the circuit training method and the interval training method on the ability of Round-House Kick for high muscle flexibility groups; b) The difference between the effect of the circuit training method and the interval training method on the Round-House kick ability for low muscle flexibility groups. A summary of the results of further tests can be seen in Table 1 below.

Table 1. Tukey Test Calculation Summary Table Results

\begin{tabular}{|c|c|c|c|c|}
\hline \multirow{2}{*}{ NO } & Group & Qcount & Qtable $(\boldsymbol{\alpha}=\mathbf{0 , 0 5})$ & information \\
\hline 1 & $\mathrm{~A}_{1}$ and $\mathrm{A}_{2}$ & 6.262986 & 2,09 & Significant \\
\hline 2 & $\mathrm{~A}_{1} \mathrm{~B}_{1}$ and $\mathrm{A}_{2} \mathrm{~B}_{1}$ & 4,977762 & $2,26$. & Significant \\
\hline 3 & $\mathrm{~A}_{2} \mathrm{~B}_{2}$ and $\mathrm{A}_{1} \mathrm{~B}_{2}$ & 0.549162 & $2,26$. & Not Significant \\
\hline
\end{tabular}

Based on the results of the hypothesis testing statistically as stated above, the discussion of the results of this study contains four main points, namely as follows: Research hypotheses which state that taekwondo in trained by the circuit training method (A1) will give the Taekwondo Round-House kick capability higher than taekwondo in trained with interval training method (A2), the truth is accepted.

The effectiveness of the circuit training method to increase the ability of the Taekwondo Round-House kick, theoretically it is better than the interval training method. The reason is because the circuit method is a form of exercise that has a special characteristic, namely very strong muscle contraction and is a response to fast loading of the muscles. The muscles involved to increase muscle endurance resulting in increased taekwondo kick abilities.

The second research hypothesis which states that the taekwondo in group that has high muscle flexibility trained by the circuit training method (A1B1) is higher the ability of the Taekwondo Round-House kick than the taekwondo in group that has high muscle flexibility trained by the interval training method (A2B1), accepted the truth.

Determination is the general capacity for performing technical (special motor) skills in a sport. Someone who has high muscle flexibility certainly has the advantage of doing the movements perfectly in the training process. 
The circuit training method is a form of exercise that has special characteristics, namely very strong muscle contraction and is a rapid loading response from the muscles involved, thereby increasing endurance so that the ability of taekwondo kicks become better.

The third research hypothesis which states that taekwondo in which has low muscle flexibility trained by the circuit training method (A1B2) is lower in Round-House kick capability, than taekwondo in that has low muscle flexibility trained by the weight training method (A2B2), the truth is not accepted.

Low muscle tone indicates that the level of readiness in learning or getting kicking ability is also low. This is evident in the process of circuit training for low muscle groups experiencing obstacles in practicing movements of a high difficulty level, which are carried out from one post to another without intervals (intervals) to rest.

For interval training methods, the low muscle group did not encounter significant obstacles, because interval training applied a rest interval for the body's recovery process before continuing the next activity.

If seen from the difference in the average interval training method is better than the circuit training method, but empirically the difference is not significant (not significant). However, recommendations for taekwondo in who have low muscle flexibility may choose circuit training and interval training if they want to improve their kicking ability.

The second research hypothesis which states that there is an interaction between the training method and muscle flexibility and the ability to Taekwondo Round-House Kick, is accepted.

Hypothesis testing carried out proves that there is an interaction between the training method and muscle flexibility of the Taekwondo Round-House kick ability. The taekwondo in group that has high muscle flexibility trained by the circuit training method achieved the Taekwondo Round-House kick capability higher than the taekwondo in group who had high muscle flexibility trained by using the interval training method.

Conversely, the taekwondo in group that had low muscle flexibility trained by the circuit training method achieved lower kicking ability compared to the taekwondo in group who had low muscle flexibility trained by the interval training method.

\section{Conclusion}

Based on the results of the research and discussion above, it can be concluded as follows: (1) overall, the results of the ability to Taekwondo Round-House kick through the application of the circuit training method are better than the interval training method, (2) for taekwondo in that has high muscle flexibility, the circuit training method is better than the interval training method for the Taekwondo Round-House kicking capability, (3) for taekwondo in which has a low flexibility, there is no significant difference between the circuit training method with the interval training method for the Taekwondo Round-House kicking ability. (4) there is an interaction between the training method and the muscle flexibility of the Taekwondo Round-House kick ability.

The implications of this finding prove: (1) Muscle flexibility needs to be considered in developing the ability of Taekwondo kicks, practicing improving kicking ability, first practicing increasing muscle flexibility, (2) Proven more effective circuit training methods to improve the ability of Taekwondo Round-House kick. 


\section{References}

Baechle T.R dan Groves B.R. Weight Training: Step to Success, USA: Human Kinetics, 1997.

Bompa, Tuodor O. Total Training for Young Champions, Compaign II: Human Kinetics, 2000.

Bompa, Tuodor O. Theory and Methodology of Training, dubugue: IOWA Kendal/hunt, pub Camp, 2009.

Bowers et al. Sport Phsyology 3 edition. USA : Dubuque wm C.Brown publisher 1992.

Bowers, Richard W and Edward L, Fox. Sport Physiology, Third Edition. USA: Wm C Publisher, 1988.

Harsono, Coching dan Aspek-Aspek Psikologis dalam Coaching, Jakarta: CV Tambak Kusuma, 1988.

Kent. M. The Oxford Dictionary of Sport Science and Medicine, New York: Oxford Univercity Press, 1994.

Rainer Martens. Successful Coaching,: Champaiign Amerika: Human Kineticks, 2004.

Rothing, Peter and Stefan Grossing, Training Slehre. Bad Homburg: Limpert Verlag, 1985.

Rushall B.S. Training for Fitness, Melbourne: Mc. Milan, 1990.

Sharkey, Brian J. Coaches Guide to Sport Physiology, University of Montana: Human Kinetics Publisher.inc.1991.

Solissa, Jonas. Teori dan Metodologi Latihan Fisik, Jakarta: RajaGrafindo Utama, 2016.

Tangkudung James, Kepelatihan Olahraga, Pembinaan Prestasi Olahraga, Jakarta: Cerdas Jaya, 2006.

Wilmore J.H dan Costill. Physiology of Sport and Exercise, USA: Human Kinetics, 1994. 